\title{
Response of Heterodera glycines and Soybean Cultivar to Tillage and Row Spacing
}

\author{
S. Y. Chen, University of Minnesota Southern Research and Outreach Center, Waseca 56093; W. C. Stienstra, \\ Department of Plant Pathology, and W. E. Lueschen, Department of Agronomy and Plant Genetics, University of \\ Minnesota, St. Paul 55108; and T. R. Hoverstad, University of Minnesota Southern Research and Outreach Center, \\ Waseca
}

\begin{abstract}
Chen, S. Y., Stienstra, W. C., Lueschen, W. E., and Hoverstad, T. R. 2001. Response of Heterodera glycines and soybean cultivar to tillage and row spacing. Plant Dis. 85:311-316.

Heterodera glycines, commonly known as the soybean cyst nematode ( $\mathrm{SCN})$, has become a major factor in soybean production in the Midwest United States. The influence of five tillage treatments and two treatments of row spacing on SCN population dynamics and yield of SCNresistant and -susceptible soybean cultivars was investigated in a corn-soybean rotation system in southern Minnesota from 1993 to 1996. No effects of tillage and row spacing were observed on nematode population density. As expected, the susceptible cultivar Sturdy consistently supported higher nematode densities than did the resistant cultivar Bell in 1993 to 1995 and Freeborn in 1996. Nematode reproduction varied among years. Predicted nematode density at equilibrium was $3,800,13,000,12,000$, and 27,000 eggs per $100 \mathrm{~cm}^{3}$ of soil in plots with the susceptible cultivar and 480,240,430, and 700 eggs per $100 \mathrm{~cm}^{3}$ of soil in plots with the resistant cultivars in 1993,1994, 1995, and 1996, respectively. The effects of tillage and row spacing on soybean yield were inconsistent. The resistant cultivars yielded 653,195 , and $435 \mathrm{~kg} / \mathrm{ha}$ more $(P<0.05)$ than the susceptible cultivar in 1994, 1995, and 1996, respectively, but no yield difference between susceptible and resistant cultivars was observed in 1993. Planting resistant cv. Bell increased the yield of the following susceptible cv. Sturdy compared with continual planting of the susceptible cultivar. A sequence with continued resistant cultivar or cultivars, however, produced a higher overall yield and lower nematode density at the end of the 4-year rotation cycle than any sequence in which the susceptible cultivar was included. Yield of resistant and susceptible cultivars was negatively related to the SCN initial population density.
\end{abstract}

The soybean cyst nematode (SCN), Heterodera glycines Ichinohe, has a major impact on soybean yield in most soybeangrowing regions of the United States and the world (31). In Minnesota, SCN has been observed in 48 counties since it was first detected in 1978 (18). Use of resistant soybean (Glycine max (L.) Merr.) cultivars along with crop rotation is an effective tactic for managing the nematode. Use of resistant cultivars, however, cannot eliminate the yield loss caused by the nematode $(12,19,30)$ because no SCN-resistant cultivar so far is immune to SCN penetration. Furthermore, planting resistant cultivars with the same source of resistance may result in a nematode population capable of reproducing at higher levels on the resistant cultivars $(8,13,32,34-40)$. Therefore,

Corresponding author: S. Chen

E-mail: chenx099@tc.umn.edu

Minnesota Agricultural Experiment Station Journal Series No. 001055004.

Financial support for this research was provided by the Minnesota Soybean Research and Promotion Council.

Accepted for publication 23 November 2000.

Publication no. D-2001-0111-01R

(C) 2001 The American Phytopathological Society resistant cultivars should be used in an integrated management program with other strategies to minimize yield loss caused by SCN.

Farmers in the United States have shifted to conservation tillage to reduce soil erosion, improve soil moisture holding capacity, and reduce labor and fuel costs $(6,25)$. Tillage practices change physical and biological processes in soil $(6,29)$ that may influence the composition of nematode species and their densities (24). The responses of plant-parasitic nematodes to tillage practices have been inconsistent (20). Decreased SCN population densities were observed in no-till compared with conventional tillage plots in Tennessee (28,29), Alabama (7), Mississippi (17), Kentucky (15), North Carolina (16), and Missouri (22). Noel and Wax (23), however, reported that the tillage effect on the SCN in Illinois was inconclusive. Greater population densities of plant-parasitic nematodes have been reported in no-till than in conventional-till plots in Iowa (27), Georgia (24), and South Carolina (10). Several studies in Georgia $(1,2)$ and Florida (14) showed little effect of tillage on nematode densities. These differences may be due to different cropping systems, soil types, environmental conditions, and their interaction with the nematode. The effect of tillage on plant-parasitic nematodes in general might also be temporary and vary over time $(4,24)$.

Our objectives were to determine the effects of tillage practices and row spacing on the SCN population density and soybean yield of resistant and susceptible cultivars under the corn-soybean rotation cropping system in Minnesota and assess tillage as a component of integrated management strategies. An abstract of this study has been published (26).

\section{MATERIALS AND METHODS}

The experiment was established in 1993 in a field near New Richland, Waseca County, MN. Corn was planted in 1992, and the field had been in a corn-soybean rotation for many years before the experiment. The soil was a Webster clay loam with $37.4 \%$ sand, $32.4 \%$ silt, $30.2 \%$ clay, $7.3 \%$ organic matter, and $\mathrm{pH} 7.8$ as measured in 1998.

Two adjacent sites in the same field were used each year. Site 1 was planted to soybean and site 2 was planted to corn in year 1 so that in each year data could be obtained from both soybean and corn plots. The experiment at each site was a split-plot design with a randomized complete block and four replicates. Five tillage treatment main plots were (i) annual fall moldboard plowing, (ii) fall moldboard plowing after harvesting corn and chisel plowing after harvesting soybean, (iii) annual fall chisel plowing, (iv) ridge tillage, and (v) no tillage. The four subplot cropping sequences were (i) 2 years of SCN-susceptible soybean cv. Sturdy with $75-\mathrm{cm}$ row spacing in the 4-year corn-soybean rotation; (ii) 2 years of SCN-resistant soybean cvs. Bell in 1993 and 1995 at site 1, Bell in 1994, and Freeborn in 1996 at site 2 with $75-\mathrm{cm}$ row spacing in the corn-soybean rotation; (iii) 1 year of Bell followed by 1 year of Sturdy with $75-\mathrm{cm}$ row spacing in the corn-soybean rotation; and (iv) 1 year of Bell with $25-\mathrm{cm}$ row spacing followed by 1 year of Sturdy with $75-\mathrm{cm}$ row spacing in the corn-soybean rotation (Table 1). Each experimental unit consisted of a plot $6 \mathrm{~m}$ long and $3 \mathrm{~m}$ wide (four rows of $75-\mathrm{cm}$ row spacing or 12 rows of $25-\mathrm{cm}$ row spacing). Corn was grown in $75-\mathrm{cm}$ rows with normal production practices for the area.

Soybean and corn were planted on 21 May 1993, 20 May 1994, 31 May 1995, and 30 May 1996. Phosphorus and potas- 
Table 1. Population densities of Heterodera glycines as influenced by tillage, cropping sequence, and row spacing

\begin{tabular}{|c|c|c|c|c|}
\hline \multirow[b]{2}{*}{ Treatment $^{\mathrm{z}}$} & \multicolumn{4}{|c|}{ Eggs $/ 100 \mathrm{~cm}^{3}$ of soily } \\
\hline & 1993 & 1994 & 1995 & 1996 \\
\hline \multicolumn{5}{|l|}{ Site 1} \\
\hline Sequence & Soybean & Corn & Soybean & Corn \\
\hline $\mathrm{S}_{75 \mathrm{~cm}}-\mathrm{C}-\mathrm{S}_{75 \mathrm{~cm}}-\mathrm{C}$ & $5,473 \mathrm{a}$ & $1,133 \mathrm{a}$ & $8,150 \mathrm{a}$ & $5,417 \mathrm{a}$ \\
\hline 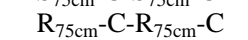 & $787 \mathrm{~b}$ & $349 \mathrm{c}$ & $477 \mathrm{c}$ & $507 \mathrm{~b}$ \\
\hline $\mathrm{R}_{75 \mathrm{~cm}}-\mathrm{C}-\mathrm{S}_{75 \mathrm{~cm}}-\mathrm{C}$ & $822 \mathrm{~b}$ & $635 \mathrm{~b}$ & $11,890 \mathrm{a}$ & $8,070 \mathrm{a}$ \\
\hline $\mathrm{R}_{25 \mathrm{~cm}}-\mathrm{C}-\mathrm{S}_{75 \mathrm{~cm}}-\mathrm{C}$ & $1,230 \mathrm{~b}$ & $360 c$ & $9,900 \mathrm{a}$ & $6,130 \mathrm{a}$ \\
\hline \multicolumn{5}{|l|}{ 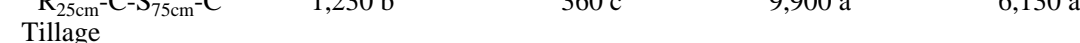 } \\
\hline Moldboard & 1,985 & 437 & 9,269 & 2,503 \\
\hline Moldboard/chisel & 2,927 & 833 & 5,934 & 5,053 \\
\hline Chisel & 1,791 & 599 & 8,184 & 3,440 \\
\hline Ridge & 1,956 & 598 & 6,844 & 7,500 \\
\hline No till & 1,731 & 629 & 7,791 & 6,659 \\
\hline \multicolumn{5}{|l|}{ Site 2} \\
\hline Sequence & Corn & Soybean & Corn & Soybean \\
\hline $\mathrm{C}-\mathrm{S}_{75 \mathrm{~cm}}-\mathrm{C}-\mathrm{S}_{75 \mathrm{~cm}}$ & 1,191 & $9,980 \mathrm{a}$ & $5,355 \mathrm{a}$ & $25,900 \mathrm{a}$ \\
\hline $\mathrm{C}-\mathrm{R}_{75 \mathrm{~cm}}-\mathrm{C}-\mathrm{R}_{75 \mathrm{~cm}}$ & 1,630 & $760 \mathrm{~b}$ & $863 \mathrm{~b}$ & $827 \mathrm{~b}$ \\
\hline $\mathrm{C}-\mathrm{R}_{75 \mathrm{~cm}}-\mathrm{C}-\mathrm{S}_{75 \mathrm{~cm}}$ & 1,403 & $612 b$ & $810 \mathrm{~b}$ & $23,148 \mathrm{a}$ \\
\hline $\mathrm{C}-\mathrm{R}_{25 \mathrm{~cm}}-\mathrm{C}-\mathrm{S}_{75 \mathrm{~cm}}$ & 1,465 & $600 \mathrm{~b}$ & $940 \mathrm{~b}$ & $20,600 a$ \\
\hline \multicolumn{5}{|l|}{ Tillage } \\
\hline Moldboard & 1,204 & 2,391 & 1,584 & 14,575 \\
\hline Moldboard/chisel & 2,044 & 4,041 & 2,037 & 18,406 \\
\hline Chisel & 1,378 & 3,394 & 1,944 & 13,252 \\
\hline Ridge & 1,116 & 2,494 & 2,469 & 26,065 \\
\hline No till & 1.871 & 2.622 & 1.925 & 15,794 \\
\hline
\end{tabular}

${ }^{\mathrm{y}}$ Nematode population density was measured at harvest, except that the nematode density in 1995 corn site (site 2) was measured in April 1996. Different letters in columns indicate significant difference at $P=0.05$ according to a least significant difference test; no letter in columns means no difference.

${ }^{\mathrm{z}}$ Cropping sequence $=1993-1994-1995-1996 ; \mathrm{C}=\mathrm{corn} ; \mathrm{S}_{75 \mathrm{~cm}}=$ soybean cyst nematode $(\mathrm{SCN})-$ susceptible soybean cultivar (Sturdy) with row spacing of $75 \mathrm{~cm} ; \mathrm{R}_{25 \mathrm{~cm}}=\mathrm{SCN}$-resistant soybean cultivars (Bell) with row spacing of $25 \mathrm{~cm} ; \mathrm{R}_{75 \mathrm{~cm}}=\mathrm{SCN}$-resistant soybean cultivars (Bell in 1993, 1994, and 1995, and Freeborn in 1996) with row spacing of $75 \mathrm{~cm}$; moldboard and chisel = plowing methods.

Table 2. Annual population changes of Heterodera glycines as influenced by tillage, crop sequence, and row spacing

\begin{tabular}{|c|c|c|c|c|}
\hline \multirow[b]{2}{*}{ Treatment $^{\mathrm{z}}$} & \multicolumn{4}{|c|}{$\mathbf{P f} / \mathbf{P i}^{\mathbf{y}}$} \\
\hline & 1993 & 1994 & 1995 & 1996 \\
\hline \multicolumn{5}{|l|}{ Site 1} \\
\hline Sequence & Soybean & Corn & Soybean & Corn \\
\hline $\mathrm{S}_{75 \mathrm{~cm}}-\mathrm{C}-\mathrm{S}_{75 \mathrm{~cm}}-\mathrm{C}$ & $7.03 \mathrm{a}$ & 0.76 & $9.26 \mathrm{~b}$ & $0.70 \mathrm{~b}$ \\
\hline $\mathrm{R}_{75 \mathrm{~cm}}-\mathrm{C}-\mathrm{R}_{75 \mathrm{~cm}}-\mathrm{C}$ & $0.62 \mathrm{~b}$ & 0.55 & $2.73 \mathrm{c}$ & $2.36 \mathrm{a}$ \\
\hline $\mathrm{R}_{75 \mathrm{~cm}}-\mathrm{C}-\mathrm{S}_{75 \mathrm{~cm}}-\mathrm{C}$ & $0.87 \mathrm{~b}$ & 1.03 & $27.37 \mathrm{a}$ & $0.81 \mathrm{ab}$ \\
\hline $\mathrm{R}_{25 \mathrm{~cm}}-\mathrm{C}-\mathrm{S}_{75 \mathrm{~cm}}-\mathrm{C}$ & $0.86 \mathrm{~b}$ & 0.87 & $42.73 \mathrm{a}$ & $1.37 \mathrm{ab}$ \\
\hline \multicolumn{5}{|l|}{ Tillage } \\
\hline Moldboard & 0.56 & 0.46 & 37.99 a & 0.56 \\
\hline Moldboard/chisel & 5.43 & 1.03 & $10.90 \mathrm{~b}$ & 1.54 \\
\hline Chisel & 1.09 & 0.93 & $20.68 \mathrm{~b}$ & 1.42 \\
\hline Ridge & 1.89 & 0.72 & $18.50 \mathrm{~b}$ & 1.90 \\
\hline No till & 1.76 & 0.86 & $14.55 \mathrm{~b}$ & 1.12 \\
\hline \multicolumn{5}{|l|}{ Site 2} \\
\hline Sequence & Corn & Soybean & Corn & Soybean \\
\hline $\mathrm{C}-\mathrm{S}_{75 \mathrm{~cm}}-\mathrm{C}-\mathrm{S}_{75 \mathrm{~cm}}$ & 1.03 & $13.16 \mathrm{a}$ & $0.63 \mathrm{~b}$ & $7.50 \mathrm{~b}$ \\
\hline $\mathrm{C}-\mathrm{R}_{75 \mathrm{~cm}}-\mathrm{C}-\mathrm{R}_{75 \mathrm{~cm}}$ & 1.27 & $0.62 \mathrm{~b}$ & $1.94 \mathrm{a}$ & $1.93 \mathrm{c}$ \\
\hline $\mathrm{C}-\mathrm{R}_{75 \mathrm{~cm}}-\mathrm{C}-\mathrm{S}_{75 \mathrm{~cm}}$ & 0.86 & $0.76 \mathrm{~b}$ & $2.72 \mathrm{a}$ & $36.35 \mathrm{a}$ \\
\hline $\mathrm{C}-\mathrm{R}_{25 \mathrm{~cm}}-\mathrm{C}-\mathrm{S}_{75 \mathrm{~cm}}$ & 1.04 & $0.57 \mathrm{~b}$ & $2.51 \mathrm{a}$ & $38.23 \mathrm{a}$ \\
\hline \multicolumn{5}{|l|}{ Tillage } \\
\hline Moldboard & 1.62 & 4.69 & 1.96 & 28.17 \\
\hline Moldboard/chisel & 1.10 & 1.93 & 2.50 & 12.45 \\
\hline Chisel & 1.05 & 5.24 & 1.58 & 24.91 \\
\hline Ridge & 0.68 & 5.22 & 2.08 & 21.56 \\
\hline No till & 0.81 & 1.80 & 1.65 & 17.93 \\
\hline
\end{tabular}

${ }^{y} \mathrm{Pf}=$ final population (egg density at harvest in the year) and $\mathrm{Pi}=$ initial population (egg density at harvest in the preceding year). Different letters in columns indicate significant difference at $P=$ 0.05 according to a least significant difference test; no letter in columns means no difference.

${ }^{\mathrm{z}}$ Cropping sequence $=1$ 1993-1994-1995-1996; $\mathrm{C}=$ corn; $\mathrm{S}_{75 \mathrm{~cm}}=$ soybean cyst nematode $(\mathrm{SCN})$ susceptible soybean cultivar (Sturdy) with row spacing of $75 \mathrm{~cm} ; \mathrm{R}_{25 \mathrm{~cm}}=\mathrm{SCN}$-resistant soybean cultivars (Bell) with row spacing of $25 \mathrm{~cm} ; \mathrm{R}_{75 \mathrm{~cm}}=\mathrm{SCN}$-resistant soybean cultivars (Bell in 1993, 1994, and 1995, and Freeborn in 1996) with row spacing of $75 \mathrm{~cm}$; moldboard and chisel = plowing methods. sium fertilizers were applied as needed according to the University of Minnesota Soil Testing Service recommendations. Each year, N (urea) was applied to corn plots at $168 \mathrm{~kg} / \mathrm{ha}$. No fertilizer was applied in soybean plots. Alachlor at a rate of $3.9 \mathrm{~kg}$ a.i./ha and linuron at a rate of $1.7 \mathrm{~kg}$ ai/ha were applied annually as preemergence herbicides to control weeds in both corn and soybean sites.

Soybean and corn were harvested in October or November. Soybean yield was determined from $4 \mathrm{~m}$ of the two central rows and the seed weight was computed at $13 \%$ moisture. Soil samples for SCN egg counts were taken within 3 weeks after harvest, except samples taken in April 1996 at site 2. A composite soil sample, consisting of five to eight cores $(2-\mathrm{cm}$ diameter by 20-cm depth) in 1993 and 1994 and 10 cores in 1995 and 1996, was collected from the two center rows in 75$\mathrm{cm}$-wide rows or six center rows in $25-\mathrm{cm}$ wide rows.

The soil samples were stored at $5^{\circ} \mathrm{C}$ until processed. Soil was mixed thoroughly before a subsample of $100 \mathrm{~cm}^{3}$ was taken. The cysts were extracted with a semiautomatic elutriator (5). Eggs were released from the cysts with a mechanical method (21) and suspended in $50 \mathrm{ml}$ of water. The number of eggs per $100 \mathrm{~cm}^{3}$ of soil was determined by counting eggs in an aliquot of 1 to $5 \mathrm{ml}$ of the egg suspension. The annual change in the nematode population density was computed as $\mathrm{Pf} / \mathrm{Pi}$, where $\mathrm{Pf}$ (final population) was the egg density at sampling each year and Pi (initial population) was the egg density from samples in the preceding year, except that the initial population of the 1996 soybean site was measured in April 1996 (= final population of 1995 corn site).

Data obtained from the two sites were analyzed separately because the treatments of crop sequence were different between the two sites (Table 1). Nematode egg counts were transformed with $\log _{10}(x+1)$ and Pf/Pi with $\log _{10}(x)$ to improve homogeneity of variances before split plot twoway analyses of variance (ANOVA). Yield was not transformed for the ANOVA. A test of least significant differences (LSD, $P$ $=0.05$ ) was used to compare means. Regressions of $\mathrm{Pf} / \mathrm{Pi}$ against $\mathrm{Pi}$ with the equation $\mathrm{Pf} / \mathrm{Pi}=a \mathrm{Pi}^{\mathrm{b}}$ (where $a$ is the scaling factor and $b$ is the rate determining variable) were performed to determine relationships between the annual population change rate and the initial nematode density and the equilibrium density (9). The relationships between soybean yield and the nematode egg densities in the preceding year after corn harvest and 2 years prior to soybean harvest were determined by the equation $Y=a e^{\mathrm{bx}}$ (where $Y$ is soybean yield, $x$ is the nematode egg density, $a$ is the maximum yield, $e$ is the base of the natural logarithm, and $b$ is the rate parameter) modified from Appel and 
Lewis (3) without determining minimum yield. For the regression analysis, the Wilk-Shapiro/Rankit Plot procedure was performed to determine whether the variables conformed to a normal distribution. Two observations of soybean yield in 1994 were identified as outliers and deleted.

\section{RESULTS}

Average SCN egg densities in fall 1992, when the tillage treatments were initially installed, were 1,497 and 2,055 eggs per $100 \mathrm{~cm}^{3}$ of soil at sites 1 and 2 , respectively. No effects from tillage practices and row spacing on SCN egg density were observed in any year (Table 1). No significant interactive effects of tillage and crop sequence on egg density were observed in any year. Sequence of soybean cultivars, however, did affect the nematode population density (Table 1). Susceptible cv. Sturdy consistently supported a higher SCN population density than did resistant cvs. Bell or Freeborn. Egg density with Sturdy ranged from 5,500 to 25,900 eggs per $100 \mathrm{~cm}^{3}$ of soil, whereas egg density with Bell or Freeborn ranged from 480 to 1,200 eggs per $100 \mathrm{~cm}^{3}$ of soil over the 4year period (Table 1$)$.

Differences in annual population change rate among tillage treatments were observed only at site 1 in the 1995 soybean site, in which the ratio $\mathrm{Pf} / \mathrm{Pi}$ was greater in plots with moldboard plowing than in plots with other tillage treatments (Table 2). No difference in $\mathrm{Pf} / \mathrm{Pi}$ was observed between 25-cm and 75-cm row spacing (Table 2). In soybean years, differences in $\mathrm{Pf} / \mathrm{Pi}$ were consistently observed among the cropping sequences. The $\mathrm{Pf} / \mathrm{Pi}$ in soybean in 1995 (site 1) and 1996 (site 2) was influenced by soybean cultivars in preceding soybean years (1993 and 1994, respectively). In 1995 site 1, the Pf/Pi where Sturdy was planted in 1993 and 1995 in 75-cm rows was 9.26, compared with 27.37 where Bell was planted in 1993 followed by Sturdy in 1995 in 75-cm rows. A similar trend was observed in 1996 at site 2. In 1995 corn plots at site 2, however, a lower Pf/Pi was observed in plots planted with Sturdy compared with Bell the preceding year.
$\mathrm{Pf} / \mathrm{Pi}$ values for most corn plots were $>1$. This does not mean the nematode egg density increased during the corn year. $\mathrm{Pf} / \mathrm{Pi}$ may be overestimated, especially when the nematode population densities are low.

Nematode population density and annual population change rate during soybean years differed among years. Pf/Pi ratios increased both in Sturdy and Bell plots in 1995 at site 1 and Freeborn in 1996 at site 2 in comparison with 1993 and 1994 at the corresponding sites (Table 3). In 1993, the final nematode population density was low and the predicted nematode population density at equilibrium was only 3,800 eggs per $100 \mathrm{~cm}^{3}$ of soil on the susceptible cultivar and 475 eggs per $100 \mathrm{~cm}^{3}$ of soil on the resistant cultivar. The population density at equilibrium represents the nematode carrying capacity of the host. The carrying capacity of the susceptible cultivar increased in the following years; in 1996, the susceptible cultivar might have been able to support a population of 27,470 eggs per $100 \mathrm{~cm}^{3}$ of soil (Table 3). The population density at equilibrium on resistant cvs. Bell and Freeborn ranged from 240 to 700 eggs per $100 \mathrm{~cm}^{3}$ of soil. If genetic composition and reproductive rate of the nematode population do not change, the resistant cvs. Bell and Freeborn should maintain a population density in this range under similar conditions.

The response of soybean yield to the tillage treatments was not consistent over the 4 years of the experiment (Table 4). In 1993, a higher yield was observed in the moldboard plowing treatment compared

Table 4. Soybean yield in soybean cyst nematode (SCN)-infested fields as influenced by tillage, cropping sequence, and row spacing

\begin{tabular}{|c|c|c|c|c|}
\hline \multirow[b]{3}{*}{ Treatment $^{\mathrm{z}}$} & \multicolumn{4}{|c|}{ Yield (kg/ha) } \\
\hline & \multicolumn{2}{|c|}{ Site 1} & \multicolumn{2}{|c|}{ Site 2} \\
\hline & 1993 & 1995 & 1994 & 1996 \\
\hline \multicolumn{5}{|l|}{ Sequence } \\
\hline $\mathrm{S}_{75 \mathrm{~cm}}-\mathrm{C}-\mathrm{S}_{75 \mathrm{~cm}}-\mathrm{C}$ & 1,864 & $1,649 \mathrm{c}$ & $\ldots$ & $\ldots$ \\
\hline $\mathrm{R}_{75 \mathrm{~cm}}-\mathrm{C}-\mathrm{R}_{75 \mathrm{~cm}}-\mathrm{C}$ & 1,770 & $2,120 \mathrm{a}$ & $\ldots$ & $\ldots$ \\
\hline $\mathrm{R}_{75 \mathrm{~cm}}-\mathrm{C}-\mathrm{S}_{75 \mathrm{~cm}}-\mathrm{C}$ & 1,757 & $2,033 \mathrm{a}$ & $\ldots$ & $\ldots$ \\
\hline $\mathrm{R}_{25 \mathrm{~cm}}-\mathrm{C}-\mathrm{S}_{75 \mathrm{~cm}}-\mathrm{C}$ & 1,656 & $1,831 \mathrm{~b}$ & $\ldots$ & $\ldots$ \\
\hline \multicolumn{5}{|l|}{ Tillage } \\
\hline Moldboard & $1,986 \mathrm{a}$ & $1,945 \mathrm{ab}$ & $\ldots$ & $\ldots$ \\
\hline Moldboard/chisel & $1,817 \mathrm{ab}$ & $1,562 \mathrm{~b}$ & $\ldots$ & $\ldots$ \\
\hline Chisel & $1,562 \mathrm{~b}$ & $1,676 \mathrm{ab}$ & $\ldots$ & $\ldots$ \\
\hline Ridge & $1,784 a b$ & $2,181 \mathrm{a}$ & $\ldots$ & $\ldots$ \\
\hline No till & $1,663 a b$ & $2,181 \mathrm{a}$ & $\ldots$ & $\ldots$ \\
\hline \multicolumn{5}{|l|}{ Sequence } \\
\hline $\mathrm{C}-\mathrm{S}_{75 \mathrm{~cm}}-\mathrm{C}-\mathrm{S}_{75 \mathrm{~cm}}$ & $\ldots$ & $\ldots$ & $2,120 \mathrm{c}$ & $1,138 \mathrm{c}$ \\
\hline C- $\mathrm{R}_{75 \mathrm{~cm}}-\mathrm{C}-\mathrm{R}_{75 \mathrm{~cm}}$ & $\ldots$ & $\ldots$ & $2,618 \mathrm{~b}$ & $1,716 \mathrm{a}$ \\
\hline$C-R_{75 \mathrm{~cm}}-C-S_{75 \mathrm{~cm}}$ & $\ldots$ & $\ldots$ & $2,719 \mathrm{~b}$ & $1,313 \mathrm{~b}$ \\
\hline $\mathrm{C}-\mathrm{R}_{25 \mathrm{~cm}}-\mathrm{C}-\mathrm{S}_{75 \mathrm{~cm}}$ & $\ldots$ & $\ldots$ & $2,982 \mathrm{a}$ & $1,393 \mathrm{~b}$ \\
\hline \multicolumn{5}{|l|}{ Tillage } \\
\hline Moldboard & $\ldots$ & $\ldots$ & 2,383 & 1,555 \\
\hline Moldboard/chisel & $\ldots$ & $\ldots$ & 2,511 & 1,346 \\
\hline Chisel & $\ldots$ & $\ldots$ & 2,598 & 1,366 \\
\hline Ridge & $\ldots$ & $\ldots$ & 3,022 & 1,454 \\
\hline No till & $\ldots$ & $\ldots$ & 2,531 & 1,255 \\
\hline
\end{tabular}

${ }^{y}$ Different letters in columns indicate significant difference at $P=0.05$ according to a least significant difference test; no letter in columns means no difference.

${ }^{\mathrm{z}}$ Cropping sequence $=1$ 1993-1994-1995-1996; $\mathrm{C}=$ corn; $\mathrm{S}_{75 \mathrm{~cm}}=\mathrm{SCN}$-susceptible soybean cultivar (Sturdy) with row spacing of $75 \mathrm{~cm} ; \mathrm{R}_{25 \mathrm{~cm}}=\mathrm{SCN}$-resistant soybean cultivars (Bell) with row spacing of $25 \mathrm{~cm} ; \mathrm{R}_{75 \mathrm{~cm}}=\mathrm{SCN}$-resistant soybean cultivars (Bell in 1993, 1994, and 1995, and Freeborn in 1996) with row spacing of $75 \mathrm{~cm}$; moldboard and chisel = plowing methods.

Table 3. Average annual population changes and predicted population density at equilibrium of Heterodera glycines following soybean ${ }^{\mathrm{Z}}$

\begin{tabular}{|c|c|c|c|c|c|c|c|}
\hline \multirow[b]{2}{*}{ Cultivar, crop site/year } & \multirow[b]{2}{*}{$\mathbf{P f} / \mathbf{P i} \pm \mathbf{S D}$} & \multicolumn{6}{|c|}{ Relationship between $\mathrm{Pf} / \mathrm{Pi}$ and $\mathrm{Pi}\left(\mathbf{P f} / \mathbf{P i}=a \mathbf{P i}^{b}\right)$} \\
\hline & & $n$ & $a$ & $\boldsymbol{b}$ & $r^{2}$ & $\boldsymbol{P}$ & $\mathbf{E}$ \\
\hline \multicolumn{8}{|c|}{ Susceptible soybean (Sturdy) } \\
\hline Site $1 / 1993$ & $7.03 \pm 10.80$ & 20 & 2,938 & -0.97 & 0.31 & $*$ & 3,800 \\
\hline Site $2 / 1994$ & $13.16 \pm 16.31$ & 20 & 2,917 & -0.85 & 0.55 & $* * *$ & 12,544 \\
\hline Site $1 / 1995$ & $26.45 \pm 32.30$ & 60 & 4,905 & -0.91 & 0.63 & $* * *$ & 11,760 \\
\hline Site $2 / 1996$ & $29.48 \pm 37.64$ & 60 & 11,015 & -0.91 & 0.84 & $* * *$ & 27,470 \\
\hline \multicolumn{8}{|c|}{ Resistant soybean (Bell/Freeborn) } \\
\hline Site $1 / 1993$ & $0.78 \pm 0.79$ & 60 & 55 & -0.65 & 0.27 & $* * *$ & 475 \\
\hline Site $2 / 1994$ & $0.65 \pm 0.96$ & 60 & 23 & -0.58 & 0.21 & $* * *$ & 239 \\
\hline Site $1 / 1995$ & $2.73 \pm 3.97$ & 20 & 24 & -0.53 & 0.30 & $*$ & 430 \\
\hline Site 2/1996 & $1.93 \pm 3.17$ & 20 & 142 & -0.76 & 0.56 & $* * *$ & 701 \\
\hline
\end{tabular}

${ }^{\mathrm{z}}$ Annual population change is expressed as $\mathrm{Pf} / \mathrm{Pi}$; Pf = final population (egg density at harvest in the year), Pi = initial population (egg density at harvest in the preceding year), $n=$ number of observations, $a=$ scaling factor, $b=$ rate determining variable, $\mathrm{E}=$ equilibrium point where $\mathrm{Pf}=\mathrm{Pi}$, and asterisks $*$ and $* * *$ indicate significance at $P=0.05$ and 0.001 , respectively. 
with the chisel plowing. In 1994, no significant difference in soybean yield was observed among tillage treatments. In 1995, yield with moldboard plowing following corn and chisel plowing following soybean was lower than ridge tillage and no tillage. No effect of tillage on soybean yield was observed in 1996.

No significant interactive effects of tillage and crop sequence on soybean yield were observed in any year. No difference in soybean yield was observed between the resistant and susceptible cultivars or between $25-\mathrm{cm}$ and $75-\mathrm{cm}$ row spacing treatments in 1993 (Table 4). There was a trend that $25-\mathrm{cm}$ row spacing produced higher yield than $75-\mathrm{cm}$ row spacing in 1994. In 1995 site 1, yield of susceptible soybean where $25-\mathrm{cm}$ row spacing was used in 1993 was lower than that where $75-\mathrm{cm}$ row spacing was used in 1993 (Table 4). This effect was not observed in 1996 site 2. Resistant cultivars (Bell in 1994 and 1995 and Freeborn in 1996), however, yielded 653,195 , and $435 \mathrm{~kg} / \mathrm{ha}$ more $(P<0.05)$ than susceptible Sturdy in 1994, 1995, and 1996, respectively, whereas there was no yield increase with the resistant cultivar in 1993 (Table 4), a cold, wet year (Table 5). In comparison with a susceptible cultivar, planting a resistant cultivar increased soybean yield of the susceptible cultivar in the following soybean season (Table 4). This could be attributed to the reduction of the nematode population density by the resistant cultivar (Table 1).

The relationship between soybean yield and nematode population density is summarized in Table 6. In 1993, no effect of egg density on soybean yield was observed. In 1994, there was a weak negative relationship between soybean yield of resistant cv. Bell and the nematode egg density. In 1993 (site 1) and 1994 (site 2), the nematode populations in different plots were similar, so that the regressions between the soybean yield and the nematode density were either insignificant or weak. In general, the soybean yields in 1995 and 1996 were negatively related to nematode egg densities after harvest of corn in the preceding year or after harvest of soybean in the preceding soybean cropping year. The coefficients of determination $\left(r^{2}\right)$ were low, indicating that other effects accounted for variation of soybean yields.

\section{DISCUSSION}

We demonstrated that tillage is not an effective tactic for managing SCN in Minnesota. Conservation tillage may slow spread of the nematode from introduction points, but it did not result in reduced SCN population density. The results of this study do not agree with results reported in previous studies, in which the SCN population density was reduced in no-till plots $(7,15-17,22,28,29)$.

The effect of tillage on the SCN population density may vary depending on many factors, such as time, environmental conditions, soil factors, cropping systems, and SCN population density. The effect of tillage on the nematode population density may take several years to manifest itself $(7,29)$. Soil in no-till plots may become more compacted as time progresses and this process may take several years $(6,16)$. Disturbing the compacted soil from no-till plots increased SCN reproduction in soybean (33).

Table 5. Temperature and precipitation recorded at the Southern Research and Outreach Center (Waseca, MN) during growing seasons in 1993-1996

\begin{tabular}{|c|c|c|c|c|c|c|c|c|c|c|}
\hline \multirow[b]{2}{*}{ Month } & \multicolumn{5}{|c|}{ Average air temperature $\left({ }^{\circ} \mathrm{C}\right)$} & \multicolumn{5}{|c|}{ Average precipitation (mm) } \\
\hline & 1993 & 1994 & 1995 & 1996 & 30-year ${ }^{z}$ & 1993 & 1994 & 1995 & 1996 & 30-year \\
\hline April & 5.8 & 7.2 & 4.8 & 5.1 & 6.2 & 13.0 & 14.2 & 9.5 & 2.8 & 7.5 \\
\hline May & 13.7 & 15.8 & 13.4 & 12.2 & 14.3 & 15.7 & 4.3 & 8.6 & 8.7 & 9.3 \\
\hline June & 18.3 & 21.2 & 21.6 & 20.6 & 19.5 & 17.3 & 8.4 & 8.1 & 13.8 & 10.4 \\
\hline July & 21.1 & 20.1 & 22.0 & 20.4 & 21.8 & 18.2 & 12.5 & 13.4 & 4.6 & 10.7 \\
\hline August & 21.2 & 19.2 & 23.1 & 20.3 & 20.2 & 21.1 & 12.6 & 11.6 & 18.0 & 10.7 \\
\hline September & 12.9 & 17.8 & 15.1 & 15.6 & 15.5 & 8.4 & 11.0 & 10.4 & 4.6 & 9.0 \\
\hline
\end{tabular}

y About $20 \mathrm{~km}$ from the experiment site.

z Average over 30 years.

Table 6. Relationship between soybean yield and density of Heterodera glycines (soybean cyst nematode [SCN]) eggs ${ }^{\mathrm{Z}}$

\begin{tabular}{|c|c|c|c|c|c|}
\hline Cultivar, year & $\operatorname{SCN}(x)$ in the year & df & Model & $r^{2}$ & $\boldsymbol{P}$ \\
\hline \multicolumn{6}{|c|}{ Susceptible (Sturdy) } \\
\hline 1993 & 1992 & 19 & $Y=1521 \mathrm{e}^{-0.000025 x}$ & 0.00 & NS \\
\hline \multirow[t]{2}{*}{1994} & 1992 & 17 & $Y=2478 \mathrm{e}^{-0.000049 x}$ & 0.09 & NS \\
\hline & 1993 & 17 & $Y=2486 \mathrm{e}^{-0.000054 x}$ & 0.10 & NS \\
\hline \multirow[t]{2}{*}{1995} & 1993 & 59 & $Y=1925 \mathrm{e}^{-0.000033 x}$ & 0.14 & $* *$ \\
\hline & 1994 & 59 & $Y=2066 \mathrm{e}^{-0.000211 x}$ & 0.17 & $* *$ \\
\hline \multirow[t]{2}{*}{1996} & 1994 & 59 & $Y=1292 \mathrm{e}^{-0.000024 x}$ & 0.09 & $*$ \\
\hline & 1996 & 59 & $Y=1400 \mathrm{e}^{-0.000072 x}$ & 0.23 & $* * *$ \\
\hline \multicolumn{6}{|c|}{ Resistant (Bell/Freeborn) } \\
\hline 1993 & 1992 & 59 & $Y=1703 \mathrm{e}^{-0.000017 x}$ & 0.00 & NS \\
\hline \multirow[t]{2}{*}{1994} & 1992 & 59 & $Y=2840 \mathrm{e}^{-0.000017 x}$ & 0.03 & NS \\
\hline & 1993 & 59 & $Y=3002 \mathrm{e}^{-0.000062 x}$ & 0.12 & $* *$ \\
\hline \multirow[t]{2}{*}{1995} & 1993 & 19 & $Y=2181 \mathrm{e}^{-0.000077 x}$ & 0.02 & NS \\
\hline & 1994 & 19 & $Y=2369 \mathrm{e}^{-0.000408 x}$ & 0.28 & $*$ \\
\hline \multirow[t]{2}{*}{1996} & 1994 & 19 & $Y=1965 \mathrm{e}^{-0.00021 x}$ & 0.55 & $* * *$ \\
\hline & 1996 & 19 & $Y=2033 \mathrm{e}^{-0.000223 x}$ & 0.37 & $* *$ \\
\hline \multicolumn{6}{|c|}{ Susceptible + resistant } \\
\hline 1993 & 1992 & 79 & $Y=1730 \mathrm{e}^{-0.000016 x}$ & 0.00 & NS \\
\hline \multirow[t]{2}{*}{1994} & 1992 & 77 & $Y=2730 \mathrm{e}^{-0.000019 x}$ & 0.02 & NS \\
\hline & 1993 & 77 & $Y=2897 \mathrm{e}^{-0.000065 x}$ & 0.11 & $* *$ \\
\hline \multirow[t]{2}{*}{1995} & 1993 & 79 & $Y=1986 \mathrm{e}^{-0.000037 x}$ & 0.13 & $* * *$ \\
\hline & 1994 & 79 & $Y=2154 \mathrm{e}^{-0.000252 x}$ & 0.22 & $* * *$ \\
\hline \multirow[t]{2}{*}{1996} & 1994 & 79 & $Y=1420 \mathrm{e}^{-0.000032 x}$ & 0.14 & $* * *$ \\
\hline & 1996 & 79 & $Y=1528 \mathrm{e}^{-0.000085 x}$ & 0.28 & $* * *$ \\
\hline
\end{tabular}

${ }^{\mathrm{z}}$ Cropping sequences for the preceding years were corn for 1993 soybean site, corn-corn for 1994, corn-soybean-corn for 1995 , and corn-corn-soybeancorn for 1996. Nematode densities were measured in the fall, except in 1996, when the nematode densities were measured at planting. $Y=$ soybean yield $(\mathrm{kg} / \mathrm{ha}) ; x=\mathrm{SCN}$ eggs per $100 \mathrm{~cm}^{3}$ of soil; NS = nonsignificant at $P=0.05$; and $*$, **, and $* * *$ indicate significant at $P=0.05,0.01$, and 0.001 , respectively. 
Crop residues may be another factor involved in the tillage effect on the $\mathrm{SCN}$ population density. Hershman and Bachi (15) observed that the negative effect of no tillage on nematode population might increase more with wheat residue than without wheat residue. The plant residue in the field of our study was corn; whereas, in the previous studies, in which reduction of SCN population was observed, wheat was generally included in the cropping sequences $(7,15,28,29)$. However, results reported from the southern United States by Koenning et al. (16) indicated that SCN density was reduced in no-till plots regardless of crop residues (wheat, corn, or soybean).

The effects of climate conditions on nematode population development and soybean yield were observed in our study. In 1993, the weather was cold and wet in the early growing season, which resulted in poor growth of soybean plants and low yield. Consequently, food for nematode development was limited. This was probably the major reason for low equilibrium density on the susceptible cultivar compared with other years (Table 3). Low soil temperatures might also have reduced nematode densities on the susceptible cultivar. In 1996, soybeans grew well and there was a large increase in nematode densities on the susceptible cultivar. Soybean yield, however, was low due to severe frost damage on 14 September.

In this study, we used a stratified soil sampling method (i.e., taking soil samples in soybean or corn rows). Using this method may have biased evaluation of the row spacing effect on SCN, because the soybean populations in rows varied with different row spacing and soybean plants affected SCN distribution in a plot (11). This sampling method also has limitations for evaluating tillage effect on SCN population because conventional tillage might dilute high populations of SCN in the soybean root zone with bulk soil elsewhere in the plot.

Our study and previous report (23) indicated that the nematode population change rates $(\mathrm{Pf} / \mathrm{Pi})$ on the resistant cultivars increased in the second cropping season compared with the first season. One possible reason might be the increase in the portion of nematodes capable of parasitizing the resistant cultivar. Another reason might be that the lower initial population density after 1 year of resistant cultivar resulted in higher $\mathrm{Pf} / \mathrm{Pi}$ because the $\mathrm{Pf} / \mathrm{Pi}$ is negatively related to $\mathrm{Pi}$ (9). Furthermore, proportional sampling error is generally greater with a lower nematode egg density than with a higher egg density, which contributed to the overestimate of $\mathrm{Pf} / \mathrm{Pi}$.

The corn-soybean annual rotation is the major crop sequence in southern Minnesota. This study indicated that 1 year of corn following susceptible soybean was not adequate to reduce the nematode population density to below a level that would cause significant damage to a subsequent susceptible cultivar. A resistant cultivar, however, effectively reduced the nematode density. Although 1 year of resistant soybean in the 4-year cycle of rotation increased yield of susceptible soybean in the fourth year, continued use of resistant soybean produced higher yield and lower nematode population at the end of the 4 years of rotation. Further study, however, is needed to determine the impact of continued use of resistant cultivars on the selection of SCN races in Minnesota fields.

\section{ACKNOWLEDGMENTS}

We thank S. Gould and C. D. Reese for technical assistance.

\section{LITERATURE CITED}

1. All, J. N., Hussey, R. S., and Cummins, D. G. 1984. Southern corn billbug (Coleoptera: Curculionidae) and plant-parasitic nematodes: Influence of no-tillage, coulter-in-row-chiselling, and insecticides on severity of damage to corn. J. Econ. Entomol. 77:178-182.

2. All, J. N., Kuhn, S. W., Gallaher, R. N, and Jellum, M. D. 1977. Influence of no-tillagecropping, carbofuran, and hybrid resistance on dynamics of maize chlorotic dwarf and maize dwarf mosaic disease of corn. J. Econ. Entomol. 70:221-225.

3. Appel, J. A., and Lewis, S. A. 1984. Pathogenicity and reproduction of Hoplolaimus columbus and Meloidogyne incognita on 'Davis' soybean. J. Nematol. 16:349-355.

4. Baird, S. M., and Bernard, E. C. 1984. Nematode population and community dynamics in soybean-wheat cropping and tillage regimes. J. Nematol. 16:379-386.

5. Byrd, D. W. J., Barker, K. R., Ferris, H., Nusbaum, C. J., Griffin, W. E., Small R. J., and Stone, C. A. 1976. Two semiautomatic elutriators for extracting nematodes and certain fungi from soil. J. Nematol. 8:206-212.

6. Denton, H. P., and Cassel, D. K. 1989. Conservation tillage and soil physical properties. Pages 16-22 in: Conservation Tillage for Crop Production in North Carolina. M. G. Cook and M. W. Lewis, eds. N.C. Agric. Ext. Serv. AG-407.

7. Edwards, J. H., Thurlow, D. L., and Eason, J. T. 1988. Influence of tillage and crop rotation on yields of corn, soybean, and wheat. Agron. J. 80:76-80.

8. Elliott, A. P., Phipps, P. M., and Terrill, R. 1986. Effects of continuous cropping of resistant and susceptible cultivars on reproduction potentials of Heterodera glycines and Globodera tabacum solanacearum. J. Nematol. 18:375-379.

9. Ferris, H. 1985. Density-dependent nematode seasonal multiplication rates and overwinter survivorship: A critical point model. J. Nematol. 17:93-100.

10. Fortnum, B. A., and Karlen, D. L. 1985. Effect of tillage system and irrigation on population densities of plant nematode in field corn. J. Nematol. 17:25-28.

11. Francl, L. J. 1986. Spatial analysis of Heterodera glycines populations in field plots. J. Nematol. 18:183-189.

12. Francl, L. J., and Dropkin, V. H. 1986. Heterodera glycines population dynamics and relation of initial population to soybean yield. Plant Dis. 70:791-795.

13. Francl, L. J., and Wrather, J. A. 1987. Effect of rotating 'Forrest' and 'Bedford' soybean on yield and soybean cyst nematode population dynamics. Crop Sci. 27:565-568.

14. Gallaher, R. N., Dickson, D. W., Corella, J. F., and Hewlett, T. E. 1988. Tillage and multiple cropping systems and population dynamics of phytoparasitic nematodes. Suppl. J. Nematol. 20:90-94.

15. Hershman, D. E., and Bachi, P. R. 1995. Effect of wheat residue and tillage on Heterodera glycines and yield of double-crop soybean in Kentucky. Plant Dis. 79:631633.

16. Koenning, S. R., Schmitt, D. P., Barker, K. R., and Gumpertz, M. L. 1995. Impact of crop rotation and tillage system on Heterodera glycines population density and soybean yield. Plant Dis. 79:282-286.

17. Lawrence, G. W., Johnson, B. B., and McLean, K. S. 1990. Influence of tillage systems on nematode population development and soybean yield responses. (Abstr.) Phytopathology 80:436.

18. MacDonald, D. H., Noel, G. R., and Lueschen, W. E. 1980. Soybean cyst nematode, Heterodera glycines, in Minnesota. Plant Dis. 64:319-321.

19. MacGuidwin, A. E., Grau, C. R., and Oplinger, E. S.. 1995. Impact of planting 'Bell,' a soybean cultivar resistant to Heterodera glycines, in Wisconsin. J. Nematol. 27:78-85.

20. McSorley, R. 1993. Effect of crop rotation and tillage on nematode densities in tropical corn. Suppl. J. Nematol. 25:814-819.

21. Niblack, T. L., Heinz, R. D., Smith, G. S., and Donald, P. A. 1993. Distribution, density, and diversity of Heterodera glycines in Missouri. J. Nematol. 25:880-886.

22. Niblack, T. L., Smith, G. S., Wrather, J. A., and Minor, H. C. 1995. Soybean yield and populations of Heterodera glycines as affected by tillage, date of planting, and cultivar. (Abstr.) J. Nematol. 27:512.

23. Noel, G. R., and Wax, L. M. 1997. Tillage and rotation effects on population dynamics of Heterodera glycines. (Abstr.) J. Nematol 29:596.

24. Parmelee, R. W., and Alston, D. G. 1986. Nematode trophic structure in conventional and no-till agroecosystems. J. Nematol. 18:403-407.

25. Phillips, R. E., Blevins, R. L, Thomas, G. W. Frye, W. W., and Phillips, S. H. 1980. No-tillage agriculture. Science 208:1108-1113.

26. Stienstra, W. C., Chen, S., Lueschen, W. E., and Hoverstad, T. 1998. Soybean cyst nematode management by tillage, rotation and resistant varieties in a soybean/corn production system. Int. Congr. Plant Pathol. Abstr. Vol. 1:3.1.2.

27. Thomas, S. H. 1978. Population densities of nematode under seven tillage regimes. $\mathrm{J}$. Nematol. 10:24-27.

28. Tyler, D. D., Chambers, A. Y., and Young, L. D. 1987. No-tillage effects on population dynamics of soybean cyst nematode. Agron. J. 79:799-802.

29. Tyler, D. D., Overton, J. R., and Chambers, A. Y. 1983. Tillage effects on soil properties, diseases, cyst nematodes, and soybean yields. J. Soil Water Conserv. 38:374-376.

30. Tylka G. L. 1997. Yield losses of Heterodera glycines-resistant soybean cultivars in Iowa in 1996. (Abstr.) J. Nematol. 29:610

31. Wrather, J. A., Anderson, T. R., Arsyad, D M., Gai, J., Ploper, L. D., Porta-Puglia, A., Ram, H. H., and Yorinori, J. T. 1997. Soybean disease loss estimates for the top 10 soybean producing countries in 1994. Plant Dis. 81:107-110.

32. Young, L. D. 1984. Effects of continuous culture of resistant soybean cultivars on soybean cyst nematode reproduction. Plant Dis. 68:237-239.

33. Young, L. D. 1987. Effects of soil disturbance on reproduction of Heterodera glycines. $\mathrm{J}$ 
Nematol. 19:141-142.

34. Young, L. D. 1992. Problems and strategies associated with long-term use of nematode resistant cultivars. J. Nematol. 24:228-233.

35. Young, L. D. 1994. Changes in reproduction of a Heterodera glycines race 5 isolate cultured on 'Cordell' and 'Bedford' soybean. J. Nematol. 26:653-655.

36. Young, L. D. 1994. Changes in the Hetero- dera glycines female index as affected by tenyear cropping sequences. J. Nematol. 26:505510.

37. Young, L. D. 1998. Influence of soybean cropping sequences on seed yield and female index of the soybean cyst nematode. Plant Dis. 82:615-619.

38. Young, L. D., and Hartwig, E. E. 1988. Selection pressure on soybean cyst nematode from soybean cropping sequences. Crop Sci. 28:845-847.

39. Young, L. D., and Hartwig, E. E. 1992. Cropping sequence effects on soybean and Heterodera glycines. Plant Dis. 76:78-81.

40. Young, L. D., Hartwig, E. E., Anand, S. C. and Widick, D. 1986. Responses of soybeans and soybean cyst nematodes to cropping sequences. Plant Dis. 70:787-791. 